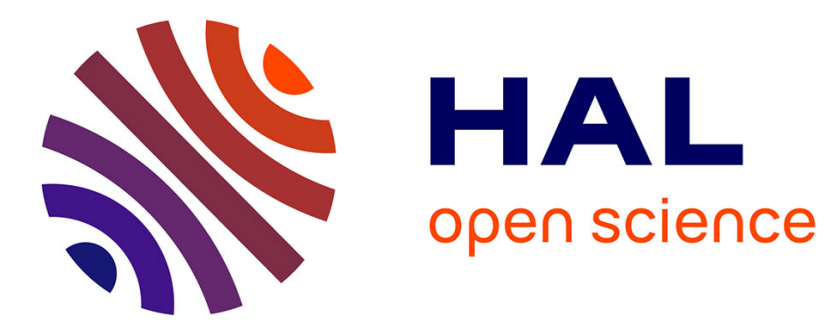

\title{
Deposition and Properties of Thin PECVD Carbon Films After Rapid Thermal Annealing
}

\author{
G. Beshkov, D. Dimitrov, S. Georgiev, T. Dimitrova
}

\section{To cite this version:}

G. Beshkov, D. Dimitrov, S. Georgiev, T. Dimitrova. Deposition and Properties of Thin PECVD Carbon Films After Rapid Thermal Annealing. Journal de Physique IV Proceedings, 1995, 05 (C5), pp.C5-615-C5-619. 10.1051/jphyscol:1995573 . jpa-00253935

\section{HAL Id: jpa-00253935 https://hal.science/jpa-00253935}

Submitted on 1 Jan 1995

HAL is a multi-disciplinary open access archive for the deposit and dissemination of scientific research documents, whether they are published or not. The documents may come from teaching and research institutions in France or abroad, or from public or private research centers.
L'archive ouverte pluridisciplinaire HAL, est destinée au dépôt et à la diffusion de documents scientifiques de niveau recherche, publiés ou non, émanant des établissements d'enseignement et de recherche français ou étrangers, des laboratoires publics ou privés. 


\title{
Deposition and Properties of Thin PECVD Carbon Films After Rapid Thermal Annealing
}

\author{
G. Beshkov, D. Dimitrov, S. Georgiev and T. Dimitrova \\ Institute of Solid State Physics, Bulgarian Academy of Sciences, Tzarigradsko Chaussee 72, Blvd. 1784 - \\ Sofia, Bulgaria
}

\begin{abstract}
In this work the properties of PECVD-carbon films before and after Rapid Thermal Annealing (RTA) are presented. The thickness of the investigated films is in the range $50-6000 \AA$. The layers are annealed at $1400^{\circ} \mathrm{C}$ for different times of $1 \mathrm{~s}$ to $3 \mathrm{~min}$ in vacuum $5 \times 10^{-5} \mathrm{Torr}$. Raman investigation has been performed before and after annealing.
\end{abstract}

\section{INTRODUCTION}

PECVD processes have been widely used as deposition methods for different semiconductor and dielectric layers which find application as active or passive elements in modern microelectron technology.

Specific construction designs in these systems are used for deposition of carbon, diamond-like and diamond layers [1-7] which are applied in the realization of different types of electron elements [8-10], working in extreme conditions (temperature, vibration, radiation etc.)

The purpose of this paper is to point out some of the peculiarities of the deposition system as well as to investigate the influence of rapid thermal annealing on some characteristics of the layers (Raman spectra/shifts and resistance).

\section{EXPERIMENTAL DETAILS AND RESULTS}

(100) P-type Si wafers with resistivity $40-60 \Omega \mathrm{cm}$ have been used in our experiments. Before the deposition of the layers, the substrates have been treated in boiling $\mathrm{H}_{2} \mathrm{SO}_{4}: \mathrm{H}_{2} \mathrm{O}_{2}(1: 1)$ for 30 min, etched for $30 \mathrm{~s}$ in $\mathrm{HF}: \mathrm{H}_{2} \mathrm{O}(1: 10)$ and rinsed in running deionized water for $30 \mathrm{~min}$. The carbon layers have been deposited in PECVD reactor (its schematic diagram is shown on Fig.1). The substrates (3) are placed in the discharge chamber (1) on the lower electrode with diameter $13 \mathrm{~cm}$. It is heated by the heater (9) up to temperature $450^{\circ} \mathrm{C}$. The surrounding wall is cooled down by water stream. The high frequency is supplied to the upper electrode (2) by high frequency generator (13.56 $\mathrm{MHz}$ ) with power $60 \mathrm{~W}$. The working pressure in the discharge chamber is $26 \mathrm{~Pa} . \mathrm{CH}_{3} \mathrm{OH}, \mathrm{C}_{2} \mathrm{H}_{5} \mathrm{OH}$ and $3 \mathrm{HC}-\mathrm{CO}-\mathrm{CH}_{3}$ have been used as supply sources for $\mathrm{C}$. In order to increase the deposition rate, the discharge space has been divided in two parts by special electrode (7) in the middle of which there is an inlet (9) with diameter $10 \mathrm{~mm}$, through which the two parts of the discharge chamber are connected. The substrate is placed against the inlet, in front of the lower electrode, which is isolated 
from the ground (the side wall of the reactor) and d.c. negative voltage is applied to it. In this way, negative ions have been intensively extracted from the plasma including carbon and oxygen radicals. This leads to the increase of the deposition rate. Table 1 shows the deposition rate of carbon from different carbon sources with and without the use of the special electrode.

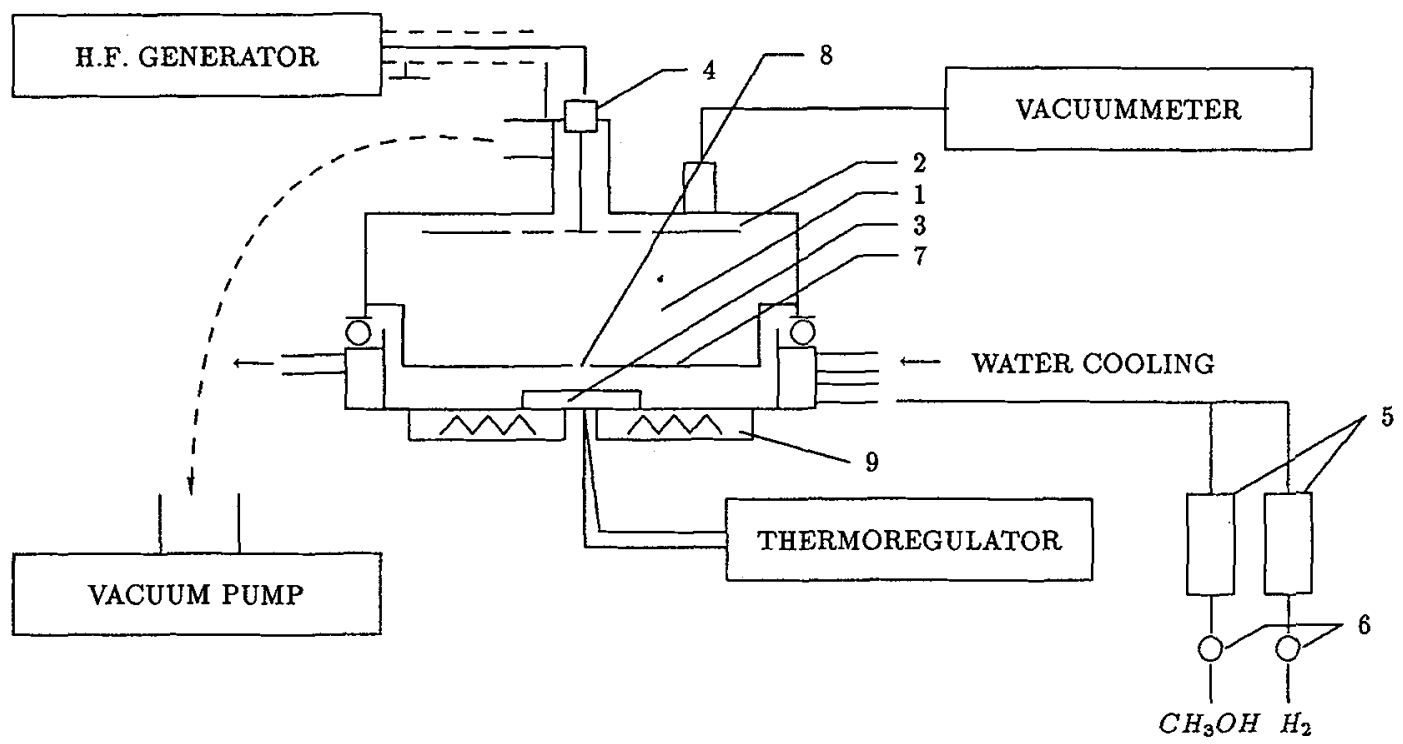

Figure 1:Schematic diagram of the PECVD reactor. 1 - Discharge chamber; 2 - H.F. Electrod; 3 Sample; 4 - Tephlon isolation; 5 - Flowmeter; 6 - Needle valves; 7 -Special electrode; 8 - Inlet (\$10) in the spacial electrode; 9 - Heater.

\begin{tabular}{|c|c|c|}
\hline $\begin{array}{c}\mathrm{C} \\
\text { source }\end{array}$ & \multicolumn{2}{|c|}{ Deposition } \\
\cline { 2 - 3 } & without special electrode & with special electrode \\
\hline $\mathrm{CH}_{3} \mathrm{OH}$ & 0.06 & 0.15 \\
${ }_{2} \mathrm{CH}_{5} \mathrm{OH}$ & 0.11 & 0.30 \\
$3 \mathrm{CH}-\mathrm{CO}-\mathrm{CH}_{3}$ & 0.15 & 0.45 \\
\hline
\end{tabular}

Table 1: Deposition rate of $C$ for different carbon sources.

From the data shown in the table it is clear that the use of the special electrode leads to the increasing of the deposition rate about 3 times.

Our Raman investigations of thin layers $(100-300 \AA)$ show the presence of peaks in the range $970 \mathrm{~cm}^{-1}$ and $800-850 \mathrm{~cm}^{-1}$, which is an indication that in the initial stage of the phase formation, $\alpha$ and $\beta$ SiC layers are obtained. Fig.2 shows the Raman spectrum of a layer deposited at pressure of $25 \mathrm{~Pa}$ in the discharge chamber, substrate temperature during the deposition $450^{\circ} \mathrm{C}$, power $120 \mathrm{~W}$ and source $\mathrm{CH}_{3} \mathrm{OH}$ and $\mathrm{H}_{2}-80 \%$ (volume). With the increasing of the thickness of the layer $(d=1000 \AA)$, diamond layers are obtained. The Raman spectrum of carbon layer with thickness $6000 \AA$ is shown on Fig.3. 


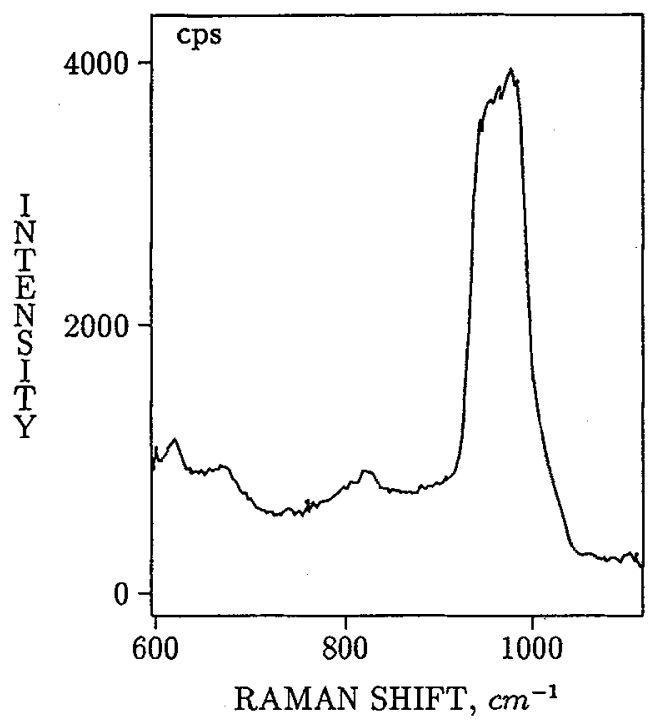

Figure 2: Raman spectrum of a layer obtained under the following conditions:pressure 25Pa, substrate temperature $450^{\circ} \mathrm{C}$, power $120 \mathrm{~W}$.

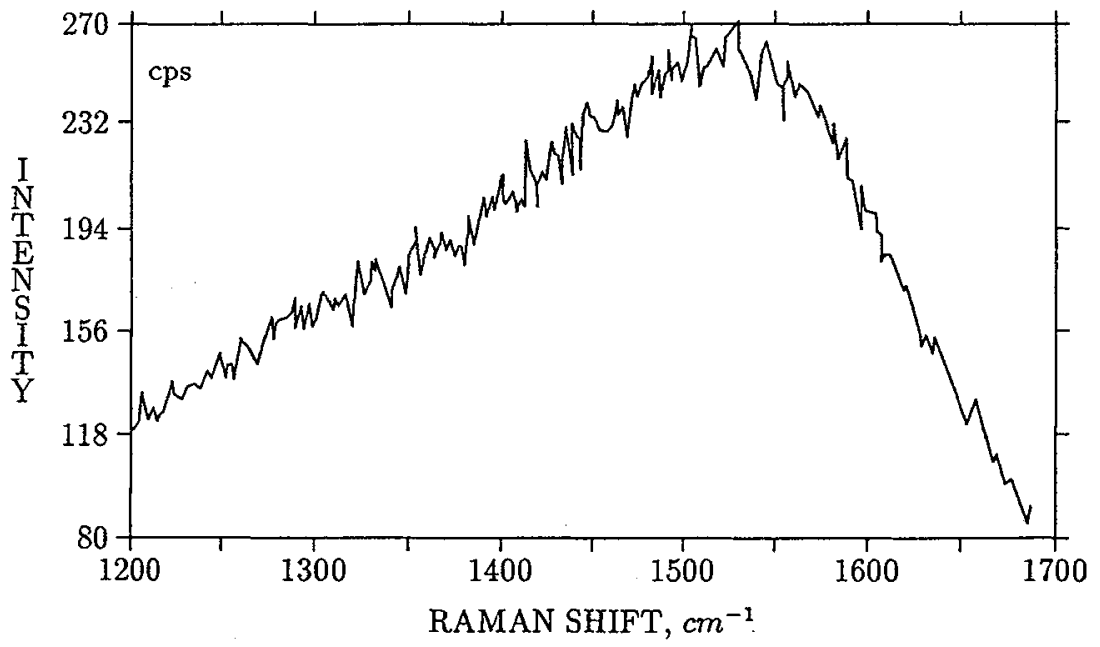

Figure 3:Raman spectrum of carbon layer with thickness $6000 \AA$.

After the deposition of the layers under the specified conditions, the wafers are subjected to rapid thermal annealing at $1400^{\circ} \mathrm{C}$ for time $1 \mathrm{~s}-3 \mathrm{~min}$ in vacuum $5 \times 10^{-5} \mathrm{Torr}$. The Raman spectrum (Fig.3) of thick carbon layer $(6000 \AA)$ before the process of Rapid Thermal Annealing, shows a clear peak with maximum at $1510 \mathrm{~cm}^{-1}$. After annealing for $1 \mathrm{~s}$, there is no change in the spectrum of the layer, but after annealing for $3 \mathrm{~s}$, two well defined peaks with maximum at 1400 and $1510 \mathrm{~cm}^{-1}$ are revealed. The peaks become more well defined increasing the annealing time. Fig. 4 shows the Raman spectrum of a layer annealed for $3 \mathrm{~s}$ and Fig. 5 - after annealing for $10 \mathrm{~s}$. Increasing the annealing time, the two peaks become better defined and practically after times greater than $3 \mathrm{~min}$ no more changes appear. Fig. 6 shows the Raman spectrum of a layer after 3 min annealing and two clear peaks are registered at 1335 and $1580 \mathrm{~cm}^{-1}$. 


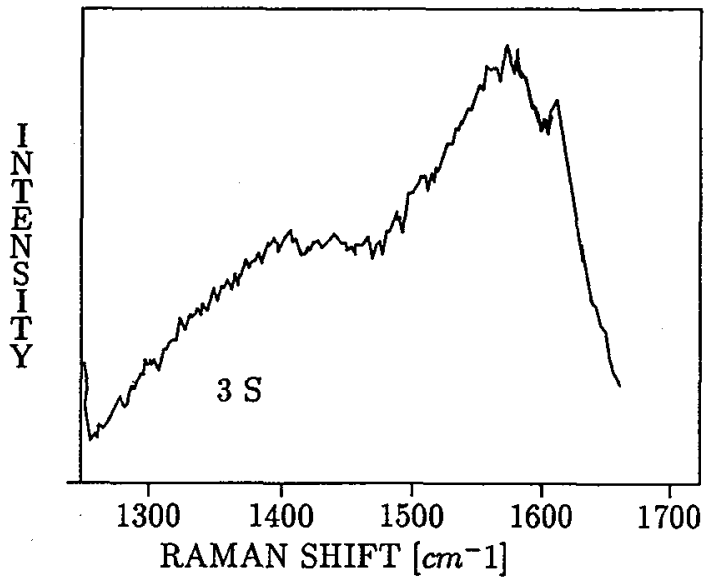

Figure 4:Raman spectrum of carbon layer after annealing for $3 \mathrm{~s}$.

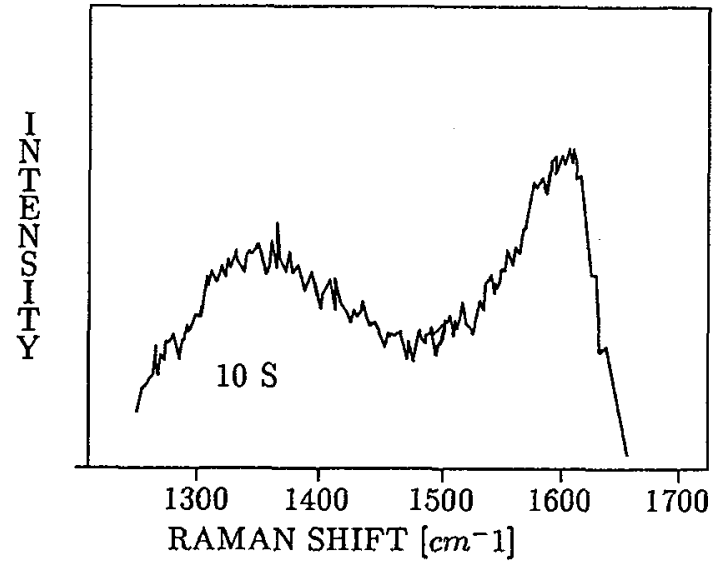

Figure 5:Raman spectrum of carbon layer after annealing for $10 \mathrm{~s}$.

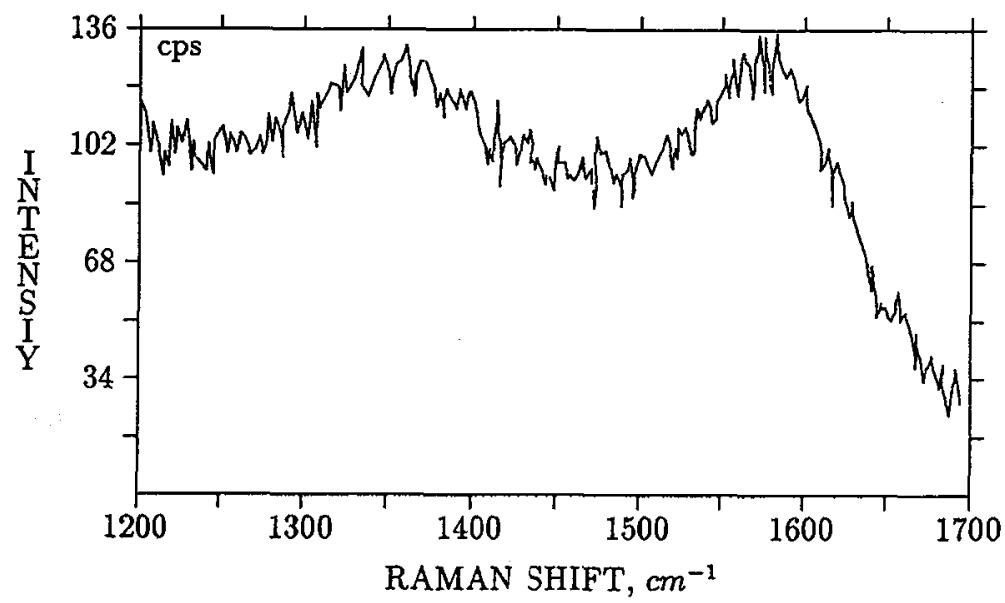

Figure 6: Raman spectrum of carbon layer after annealing for $3 \min d=6000 \AA$. 
The measurements of the resistivity of the layers show that for annealing times 1-3 $\mathrm{s}$ a sharp increase in the resistivity is registered reaching values of $10^{7} \Omega$. For annealing times $10-50 \mathrm{~s}$ a strong decrease of the resistivity is obtained up to $400 \Omega$, and after annealing for 1-3 min it reaches a value of $200 \Omega$ which remains unchanged independently of the annealing time. These results may be due to different phase transitions in the structure of the carbon layers with a very high resistivity for the short annealing times (1-3 s) and reaching the graphite structure for annealing times greater than $1 \mathrm{~min}$.

\section{CONCLUSIONS}

It has been established that the deposition rate of carbon layers in PECVD reactor is increased about 3 times when a special electrode with an inlet of $1 \mathrm{~cm}$ in the middle is used.

The rapid Thermal Annealing leads to the appearance ot two peaks in the range 1335 $1580 \mathrm{~cm}^{-1}$ in the Raman spectra and drastically increases the resistivity of the layers for annealing times 1-3 s.

\section{Acknowledgements}

This work has been supported by the Ministry of Science, Education and Technology in the frame of Project 326.

\section{References}

[1] Bachmann P.K., Leers D. amd Lidtin H., Diamond and Related Materials 1 (1991) 1-12.

[2] Kokano, Solid St. Electronics 34 (1991) 139-141.

[3] Yasto and Kamo M., Surf. Coat. Technol. 39-40 (1989) 183-198.

[4] Mucha J.A., Flamn D.L. and Ibbotsom D.E., J. Appl. Physics 65 (1989) 3448-3452.

[5] Messier R., Growth of Monocrystaline $6 \mathrm{HSiC}$, Proc. of $5^{\text {th }}$ European Conference on Diamond, Diamobd-like and Related Materials, September, (1994), Tuscany, Italy.

[6] Komath M., Zambare M., Gangal S. and Kulkarni S., Diamond and Related Materials 4 (1994) 15-19.

[7] Grill A. and Patel V., Diamond and Related Materials 4 (1994) 62-68.

[8] Borh S., Haubner R. and Lux B., Diamond and Related Materials 4 (1994) 133-144.

[9] Hant W., Muller C., and Binggeli M., Thin Solid Fims 236 (1993) 87-90.

[10] Davis R., Physica B 185 (1993) 1-15. 